\title{
Theoretical Aspects of the Assessment of Economic Entities Financial Condition
}

\author{
Vladimir Vladimirovich Glukhov ${ }^{1}$ \\ ${ }^{1}$ Far Eastern Federal University, Vladivostok, Sukhanova street, 8, Russian Federation \\ Correspondence: Vladimir Vladimirovich Glukhov, Far Eastern Federal University, 690950, Vladivostok, \\ Sukhanova street, 8, Russian Federation. E-mail: gvv61@fromru.com, gvv61@bk.ru
}

Received: July 6, 2014 Accepted: July 20, 2014 Online Published: November 27, 2014

doi:10.5539/ass.v10n24p50 URL: http://dx.doi.org/10.5539/ass.v10n24p50

\begin{abstract}
The economic attractiveness of business entities for investors is an essential element in making decisions on the investment of financial resources into their development. An assessment of their financial condition plays an important role here, being an important characteristic of economic activity. The financial condition of economic entities is one of the most important indicators that reflect the productive capacity, distribution and use of own and borrowed financial resources, their adequacy and solvency. The issues of assessment of the financial condition of economic entities receive a lot of attention in the works of both domestic and foreign researchers, who offer a variety of valuation multiples, including various indicators, but the problem of multi-criteria selection has not yet been finally resolved. However, the financial condition of the economic entities as a scientific category is not considered by all academic economists, whose points of view and methods to its definition differ from their belonging to a relevant school of sciences.
\end{abstract}

Keywords: assessment of the financial condition, financial sustainability, solvency, liquidity, economic entities

\section{Introduction}

Formation of market relations in the Russian Federation is characterized by high volatility, instability and disproportionate development of the material and non-material production in various sectors of the national economy, competition between economic entities both on the commodity and capital markets.

Theory and practice of financial management are now becoming more and more relevant, because the owners of economic entities gradually realize that the management of the enterprise is largely carried out by means and with help of finance.

Financial indicators characterize the performance of any economic entity, regardless of the size and proprietary form, and are the main indicators of diagnoses that indicate the changes and allow developing a set of measures to support the economic equilibrium (Bobyleva, 2013, p. 12).

However, there is a need to investigate the nature of the research of the discussion issues in determining the uniformity of interpretation of assessment the financial condition of economic entities, as well as inclusion of other concepts, such as economic entities, self-regulatory entities of the economic domain, businesses, organizations, firms, institutions, organizations, companies, and so on. (Glukhov \& Glukhov, 2013).

The financial condition of economic entities is directly dependent on the results of their industrial, commercial and financial activities. The purpose of the assessment of the financial condition of the company is to improve production profitability and strengthen financial stability as a basis for stable operation and fulfillment of its obligations to the budget, credit and financial institutions, suppliers and other contractors.

Assessment of the financial condition can be used both by the economic entity itself and the external market entities for transactions, contract executions, or for provision of information about its financial condition to third parties, representing either their own interests or the interests of the owners (founders).

Other economic entities, investors, credit and financial institutions and public authorities can act as the third parties, who treat the assessment of the financial condition as the main indicator when making decisions on investments, lending or entering into contracts for involvement in various projects. 


\section{Topicality of Research}

\subsection{Criteria for Assessment of the Financial Condition}

Transformation processes taking place in the Russian economy are accompanied by transformation of the relationships arising between the state, economic entities and households, which represent a public (centralized) and private (decentralized) sectors of the financial system.

During the transition to functioning in a market economy, many Russian economic entities found themselves in a difficult financial situation, the risks of possible insolvency and bankruptcy increased, which generates an objective need for more efficient mechanisms to assess managerial decision-making that minimize the risk of mistakes of an economic nature.

In their activities, business entities are involved in various types of financial relations with the state, other economic entities and the public, related to the formation and use of centralized and decentralized financial funds.

In this case, the financial relations of economic entities involve not only cash settlements, but also other tangible and intangible assets in terms of value, as well as economic outcomes and their determinants (income, expenses, mandatory payments, etc.) that ultimately affect the financial condition.

To prevent this, in order to adjust the economic and investment policy, the owners of economic entities need to conduct a timely assessment of their financial condition and a comparative analysis of performance indicators in relation to competitors.

In the market economy, the performance of the economic entities, regardless of the size and proprietary form, largely depends on the stability of their financial condition and evaluation methods and development prospects used thereat (Eletskikh, 2010, p. 27).

If the economic entity is financially stable in its development, it has advantages over other economic entities operating in the same segment of the commodity market to obtain loans and other borrowings, attract investments, in the choice of business partners, staff recruitment and etc.

The financial condition of economic entities is assessed primarily by its solvency and sustainability.

Solvency reflects the ability of the economic entity to make payments under its obligations in the specified time period, to employees, other legal entities, individuals and the state.

Popov V. notes that the solvency of the business entity is its mobility supportability to repay short-term debt. The most reliable indicator of the solvency should be considered the ratio of cash and marketable securities to the amount of short-term debt (Popov, Mlodik, \& Zverev, 2009, p. 128).

The financial sustainability refers to the solvency of the business entity in time while meeting the condition of the balance between equity and debt and is defined as the characteristics of the level of risk of its activities in terms of balance or surpluses, while the financial stability ratio shows the proportion of assets financed by equity.

The higher the financial sustainability of the economic entity, the less it is affected by changes in market conditions and the lower the risk of a possible bankruptcy.

According to Krush, Z. and Zaporozhtseva L., monitoring of financial stability and the establishment of life-cycle stages may be based on absolute figures: according to the method of comparison of supplies and costs with the sources of their formation and non-current and current assets with the sources of their coverage. As a result, the life-cycle stages of financial sustainability are determined, corresponding to its main types: absolute or normal sustainability, instability or crisis financial condition (Krush \& Zaporozhtseva, 2011, p. 64).

Financial sustainability of the economic entity is characterized by the condition of financial resources that meets the development needs, market requirements and conditions of operating activities.

Independent search for a business partner also determines the presence of sound criteria of choice from the standpoint of financial sustainability and competitiveness.

In his turn, Batkovsky A. believes that the association of sustainability of an economic entity only with its financial condition is extremely limited, because even after bankruptcy and transfer to the new owner, its production potential can be fully preserved. The connection between the sustainability of the economic entity and not only its financial and economic situation, but also its management system, structure, production and process parameters, their dynamics, i.e. the state of the production process, seems to be no less adequate.

Therefore, when analyzing the sustainability of the economic entity, it is advisable to use a systematic approach: 
it is necessary to consider not only financial, but also other factors that affect it, while considering both economic and financial sustainability (Batkovsky, 2011, p. 30).

\subsection{Indicators of Financial Condition}

The financial condition of the economic entity is characterized by indicators that describe its ability to develop and operate successfully in a competitive market economy in the operational and strategic aspects.

The financial condition in operational (short-term) aspect is evaluated using indicators that characterize the liquidity and current debt of the economic entity, and in strategic (long-term) aspect-with the help of indicators that characterize its financial sustainability and solvency.

The boundaries of financial sustainability are critical indicators at reaching which the quantitative changes in financial resources generate a qualitative leap that changes, in particular, not only their quality, but also the very financial sustainability of the economic entity.

The lower limit of the financial sustainability is the financial condition of the economic entity at which it loses not only the quality of its products or services required by the market, but also the opportunity to operate independently in its respective sectors of the economy, which is manifested in the absence of the capacity for further development.

Yepifanova T. notes that financial sustainability can be assessed in terms of short-term and long-term prospects. In the first case, the criteria for assessment of the financial sustainability include liquidity and solvency of the economic entity.

The liquidity of the economic entity is a generic term which refers to the availability of equity in the amount theoretically sufficient to cover short-term liabilities.

Balance liquidity involves the economic entity finding means of payment from internal sources (sale of assets). The concepts of solvency and liquidity are very close, but the latter should be considered a broader concept (Yepifanova, 2012, pp. 73-74).

In connection with the above, it seems necessary to distinguish between the concepts of "financial sustainability" and "financial stability".

A large number of economic entities experience various economic difficulties associated with financial instability and temporary insolvency in the current economic conditions.

This is the reason for the need to attract "expensive" borrowed money or divert resources from the equity turnover. Economic entities that do not meet the specified maturity dates of accounts payable come to bankruptcy and subsequently get liquidated.

Ability to self-sufficiency and self-sustainability is the basis for economic activities of businesses, so the measures taken to overcome the economic problems in their activities may be more efficient if the unstable financial condition will be identified at the earliest stages.

The laws of the market economy, which domestic economic entities find difficult to adapt to, require constant circulation of money in various sectors of the economy based on effective demand.

The economic attractiveness of business entities for investors is an essential element in making decisions on the investment of financial resources into their development.

The financial condition of economic entities is one of the most important indicators acting as integral characteristics of their economic activity that reflects the productive capacity, distribution and use of own and borrowed financial resources, their adequacy and solvency.

The financial condition of economic entities is determined by a combination of factors of production and is characterized by the models, methods and indicators that reflect the presence, location and use of financial resources.

The existing discussion and the lack of uniformity in the theoretical and methodological rationale for assessment of the financial condition of economic entities greatly reduce the possibility of efficient formation and use of management tools and mechanisms.

\section{Discussion}

\subsection{Theoretical Aspects of the Assessment of the Financial Condition of Economic Entities}

The issues of assessment of the financial condition of economic entities receive a lot of attention in the works of both domestic and foreign researchers, who offer a variety of valuation multiples, including various indicators, 
but the problem of multi-criteria selection has not yet been finally resolved.

However, the financial condition of the economic entities as a scientific category is not considered by all academic economists, whose points of view and methods to its definition differ from their belonging to a relevant school of sciences.

The Russian scientific literature, courseware and textbooks often use different interpretations of the financial condition of economic entities, such as financial sustainability, financial stability, financial position, financial potential, financial security, financial independence, financial well-being, etc. (Kovalev, 2010; Litovchenko, 2014; Melnik \& Efimova, 2014; Sheremet, 2009; Borodin, Belokrylova, \& Shash, 2013; Shtembulyak, 2010; Piskunova, 2010; Vorobiev, 2011; etc.).

In their turn, foreign researchers and Russian scientists, who share their point of view, interpret the financial condition of the economic entities as their property position, liquidity, business activity, the value or reliability of business, etc. (Eletskikh, 2010; Kirov, 2011; Redhead \& Hughes, 1988; Helfert, 2001; Bernstein, 1989; Heddervik, 1996; Gray, Sidney, Needles, Belverd, Gray, \& Sidney, 1999; Drury, 2007; Coperland, Koller, \& Murrin, 2000; etc.).

Richard J. notes that for a long time in the West, the analysis of the economic activity of the enterprise has often been limited to the analysis of its financial condition, which was largely reduced to the study of the profitability and solvency, with little time spent on studying other indicators to measure results (Richard, 2007, pp. 7-8).

According to Korshunova E., the reasons for such a wide use of these concepts are not only due to their versatility, but also their inconsistency, imperfection of the concept of sustainable development, especially in its economic aspect, the incompleteness of information to measure the degree of sustainability and making competent management decisions, lack of a unified formal approach to address this issue (Korshunova, 2013, p. 82).

Tuktarova L. notes that analyzing the works of local authors who define the essence of the concept of "economic sustainability", it can be argued that the diversity of existing approaches is connected with the fact that in all these studies, the economic sustainability is not singled out as a separate category, because the domestic analysts in most cases consider only some of its components (Tuktarova, 2009, p. 145).

Assessment of the financial condition allows external entities to determine the financial capacity of the economic entity in the long term. Thus, many leaders of economic entities, including representatives of the public sector of the economy, prefer to invest the least of equity and fund it with money borrowed.

However, if the "equity-debt" structure has a significant shift to the debt, the commercial organization can go bankrupt when several creditors suddenly claim their money back in an "inappropriate" time for it (Mishineva, 2013, p. 118).

\subsection{The "Consumers" of the Assessment Data on the Financial Condition of Economic Entities}

Various users of the financial statement are engaged in the analysis of the financial condition of the economic entities: shareholders, investors (to examine the efficiency of the use of borrowed funds), banks (to assess the lending terms and the extent of the risk), suppliers (to receive payments in time), the fiscal authorities (to monitor receipt of mandatory payments to the budget and non-budget funds), etc.

The directions of assessment at different users of financial statements often overlap. If the economic activities of the economic entity can be divided into components-investment, operating and financial,-then the overlap of interests of the founder (owner), the manager and the lender can be distinguished. The potential disadvantage of this approach can be immediately traced: the devotion of each of them only to their own economic interests.

The fact should be taken into account that in the transition to a market economy, the role and objectives of the accounting policies have changed dramatically for economic entities of all proprietary forms in Russia that self-determine the areas and types of economic activity, choose business partners, create subsidiaries, etc.

Entering into relationships with other business partners, the economic entity must prove its sustainability and solvency, which suggests the need to assess its financial condition, which should be available to all interested users.

Consequently, the information on the financial condition of economic entities is increasingly turning from accounting and control means into grounds for decisions, and the efficiency of the organization of economic activity depends on its timeliness, quality and reliability. 


\section{Methods Used to Assess the Financial Condition of Economic Entities Enterprise}

Methods to assess the financial condition of economic entities used in the Russian practice are based primarily on the assessment of the company's property and the sources of its formation.

The analysis shows that this approach estimates only certain aspects of the financial condition of economic entities, generalizes internal and external relationships, and divides the general overview of the assessment into separate components.

However, modern methods to assess the financial condition of the economic entities must provide sufficient information to make informed management strategic decisions.

Detailization of the methods of financial analysis depends on the objectives, availability of a variety of factors to ensure the activities of economic entities, and assumes its organization as the rapid analysis and the detailed analysis of financial condition.

According to Kovalev V., the study of financial analysis involves a number of areas of focus.

The first approach involves the activities of the so-called "school of empirical pragmatists" who were trying to establish a set of relative indicators that could answer the question of whether the company will be able to settle its short-term obligations.

The second approach is caused by the activities of the "school of statistical financial analysis", the basic idea of which was that the analytical coefficients calculated according to the financial statements for the purposes of assessment of the financial condition of the company are useful only if there are criteria with the threshold values to compare these coefficients with.

The third approach is associated with the activity of a "school of multivariate analysts", which was based on the connection of partial coefficients characterizing the financial condition and the efficiency of the current activities of the company (gross income, turnover of assets, supplies, settlements and so on.) and general indicators of financial and economic activity (return on advanced capital).

The fourth approach is associated with the appearance of a "school of analysts engaged in diagnostics of the bankruptcy of companies" that have focused on the financial stability of the company (strategic aspect), preferring a prospective analysis of the retrospective.

The fifth approach represents a "school of stock market participants", the representatives of which believe that the value of statements is the possibility of its use for predicting the level of efficiency of investment in certain securities and the extent of the associated risks. This approach has been developed mainly by scientists and has not yet received recognition from practitioners (Kovalev, 2010, p. 133).

In solving practical problems of assessing the financial condition of economic entities, there are contradictions between the objectively obtained solutions and requirements of the party that conducts a study, where the way out of these situations is to review the performance indicators.

The use of horizontal and vertical balance is widespread in domestic and foreign literature, but the methods that are offered in its conduct allow analyzing individual balance sheet items and do not allow for an overall assessment of the financial condition of the company.

A widely used method to assess the financial condition of the economic entity is to predict the probability of bankruptcy by using multivariate discriminatory analysis. The models developed by foreign scientists are most frequently used to assess the threat of bankruptcy.

The Russian economists also offer models of bankruptcy risk forecast, but in general, there are not many domestic developments in the modeling of the condition of the economic entities, and foreign models are not fully adapted to the Russian reality and cannot be directly used to assess their financial condition.

Therewith, implemented systems of indicators are advisable for multicriteria comparative assessment of the economic condition of enterprises.

Issues of the use of several (three or more) performance indicators to assess the financial condition of the company are not sufficiently worked out in the scientific and academic literature. The proposed methods are mainly focused on the selection of a single alternative and do not include further analysis.

\subsection{Assessment of the Financial Condition of Small Businesses}

In the context of transition of Russia to a market economy, the role and objectives of the economic departments of the economic entities of all proprietary forms have changed dramatically. 
This is due to the expansion of opportunities of the economic entities that independently choose the accounting policies, determine the procedure of depreciation write-offs, the procedure of formation of reserves for various purposes; define business partners, destinations and types of economic activity, create subsidiaries and associates, etc.

The managers of the economic entities have to make decisions on these issues, both of economic and other nature, which affect the level of production costs; about the types and terms of mandatory payments, etc.

At the same time, the role and functions of the economic department depend on the size of economic entities and proprietary form, and particularly affects small businesses and micro-enterprises, a large number of which leads to the fact that they don't employ qualified economists, and their owners have to solve the issues of running the business independently, relying on their own intuition and experience.

It should be noted that the specific features of a small business are combination and the contradiction of the interests of different groups of users of information due to the fact that as a rule, owners and investors are both manager and employee in one person.

The difficulty in assessment of the financial condition of small businesses is that the economic interests of the economic entity and its owner are interconnected in this area of business-all tangible and intangible assets are inseparable. Therefore, the assessment will be very conditional even in the presence of accounting.

The analysis of the economic literature and available statistics on the activities of small businesses shows an increasing role of small businesses, even in countries with developed market economies, although their financial sustainability remains relatively low in the meantime.

Small businesses play a vital role in economic and social life of the developed countries. The promotion of small business by the state in the interests of society and the state is considered the norm in world practice.

The task of the state is not to simply hand over financial, technical and other resources to the small businesses and support them at all costs, but also to create legal and economic conditions for their operation and ability to thrive in the marketplace.

\section{Conclusion}

Assessment of the financial condition of the economic entity is an integral part of running the business, which defines the conditions for the formation of sufficient liquidity, profitability, optimal financial structure of capital.

Based on the above analysis of educational and academic literature, a conclusion can be made that in most cases the assessment of the financial condition of the economic entity uses the concept of the financial sustainability, which in the scientific literature is treated as an economic, industrial, business, investment, etc. sustainability.

Thus, the information on the financial condition of economic entities is increasingly turning from accounting and control means into grounds for decisions, and the efficiency of the organization of their economic activity depends on its timeliness, quality and reliability.

\section{References}

Batkovsky, A. M. (2011). Methodological problems of improving the analysis of the financial sustainability of the enterprise of the radio electronic industry. Economics, Business and Law, 1(1), 30-44.

Bernstein, L. A. (1989). Financial Statement Analysis: Theory, Application and Interpretation (4th ed., p. 1003). Richard D Irwin, Inc.

Bobyleva, A. Z. (2013). Financial management: Problems and solutions (p. 903). Moscow: Yurait.

Borodin, A. I., Belokrylova, O. S., \& Shash, N. N. (2013). Theoretical aspects of the management of the financial potential of the enterprise. Economics in the Industry, 1, 76-82.

Coperland, T., Koller, T., \& Murrin, J. (2000). Valuation: Measuring and Managing the Value of Companies (3th ed., p. 492). John Wiley \& Sons.

Drury, K. (2007). Management and cost accounting (p. 735). Moscow: UNITY-Dana.

Eletskikh, S. Y. (2010). Management of financial sustainability of the enterprise: Theory and methodology (p. 180). Kramatorsk: DGMA.

Glukhov, V. V., \& Glukhov, E. V. (2013). Meaning and Essence of Scientific Concept «Business Finance» in Market-Oriented Economy. World Applied Sciences Journal, 25(10), 1405-1408. 
Gray, S. J., Needles, B. E., \& Gray, Jr. S. J. (1999). Financial Accounting: A Global Approach, Houghton Mifflin (Academic, p. 599).

Heddervik, K. (1996). The financial and economic analysis of enterprises. In D. P. Lukichev, Y. N. Voropaev, \& A. O. Lukicheva (Eds.), Finance and Statistics (p. 192). Moscow.

Helfert, E. A. (2001). Financial Analysis: Tools and techniques. A Guide for Managers (p. 480). McGraw-Hill.

Kirov, A. (2011). Management of financial sustainability in the context of performance management of the company. Bulletin of the Institute of Economics of the Russian Academy of Sciences, 3, 305-313.

Korshunova, E. T. (2013). Procedure for assessing the sustainability of economic development of the industrial enterprise. Economic Sciences, 1(98), 81-84.

Kovalev, V. V. (2010). Financial analysis (p. 268). Moscow: Finance and Statistics.

Krush, Z. A., \& Zaporozhtseva, L. A. (2011). Matrix model to assess the financial sustainability and creditworthiness of the company. Finance and Credit, 25(457), 63-67.

Litovchenko, V. P. (2014). Financial analysis (p. 216). M: ITK Dashkov \& Co.

Melnik, M. V., \& Yefimova, O. V. (2014). Analysis of financial statements (p. 451). Moscow: Omega-L.

Mishineva, O. M. (2013). Assessment of the financial sustainability of the enterprises with the methods of financial analysis in the transition to International Financial Reporting Standards. Economics and Management, 1, 117-122.

Piskunova, I. V. (2010). Evolution of interpretation of the sustainability of the organization. Economic Sciences. 5(66), 71-74.

Popov, V. M., Mlodik, S. G., \& Zverev, A. A. (2009). Analysis of financial solutions in business (p. 216). Moscow: KnoRus.

Redhead, K., \& Hughes, S. (1988). Financial Risk Management (p. 200). Gower Pub Co.

Richard, J. (2007). In L. P. Belykh et al. (Eds.), Audit and analysis of the economic activity of the enterprise (p. 375). Moscow: Audit, UNITY.

Sheremet, A. D. (2009). Comprehensive analysis of the economic activity (p. 415). Moscow: INFRA-M.

Shtembulyak, D. O. (2010). Financial stability of enterprises in market turbulence. Economics and Management, 1, 119-123.

Tuktarova, L. R. (2009). Analysis of approaches to the definition of "economic sustainability of the enterprise". Bulletin of SSEI, 4(28), 144-167.

Vorobiev, A. V. (2011). Domestic methodological approaches to the development of the financial strategy of the enterprise (genesis and analysis). Finance and Credit, 16, 54-57.

Yepifanova, T. V. (2012). Main provisions of the analysis and assessment of financial sustainability of small and medium-sized businesses in the static. Financial Research, 4, 72-77.

\section{Copyrights}

Copyright for this article is retained by the author(s), with first publication rights granted to the journal.

This is an open-access article distributed under the terms and conditions of the Creative Commons Attribution license (http://creativecommons.org/licenses/by/3.0/). 